\title{
Aberrant Adrenocortical Tissue Associated with Resected Lipoma of Spermatic Cord in an Adult
}

\author{
${\text { Motoi Takeuchi }{ }^{*} \text {, Koichi Okuya }}^{2}$, Ryu-Ichi Kato', Noriomi Miyao' ${ }^{1}$, Yasuhiro Konishi ${ }^{3}$ \\ ${ }^{1}$ Department of Urology, Muroran City General Hospital, Muroran, Japan \\ ${ }^{2}$ Department of Gastroenterological Surgery, Muroran City General Hospital, Muroran, Japan \\ ${ }^{3}$ Department of Pathology, Muroran City General Hospital, Muroran, Japan \\ Email: ${ }^{*}$ murohosp160@kujiran.jp
}

Received 15 October 2014; revised 26 November 2014; accepted 18 December 2014

Academic Editor: Sung-Goo Chang, Kyung Hee University Medical Center, South Korea

Copyright (C) 2014 by authors and Scientific Research Publishing Inc.

This work is licensed under the Creative Commons Attribution International License (CC BY).

http://creativecommons.org/licenses/by/4.0/

(c) (i) Open Access

\begin{abstract}
Aberrant adrenocortical tissue in spermatic cord is rare in adult population. We report an unusual case of a 52-year-old male patient with an aberrant adrenocortical tissue which is incidentally resected within lipoma of spermatic cord and identified on microscopic examination. Although he was diagnosed with right inguinal hernia, there was no significant hernia orifice intraoperatively. When the 2nd operation by anterior open approach was undergone, there was a fat-like tissue adhered to the spermatic cord. It was removed and the histopathological finding first revealed aberrant adrenocortical tissue in the resected lipoma of spermatic cord (Figure 1). This abnormal tissue is usually found incidentally during inguinal operation. In general, most of the aberrant adrenal tissue becomes atrophic by adult life. Moreover, it is not clinically significant and also not associated with endocrine abnormalities.
\end{abstract}

Keywords

Aberrant Adrenocortical Tissue, Inguinal Hernia, Spermatic Cord, Lipoma, Adult

\section{Introduction}

In 1740, Morgagni first described aberrant adrenal tissue in the vicinity of the adrenal gland [1]. Although aber-

\footnotetext{
*Corresponding author.
}

How to cite this paper: Takeuchi, M., Okuya, K., Kato, R.I., Miyao, N. and Konishi, Y. (2014) Aberrant Adrenocortical Tissue Associated with Resected Lipoma of Spermatic Cord in an Adult. Open Journal of Urology, 4, 151-154. 
rant adrenal tissue near the adrenal gland is common, aberrant adrenal tissue in inguinal structures such as spermatic cord and hernia sac is rare, especially in adult population. The incidence of aberrant adrenal tissue in spermatic cord of adults is significant lower at 1\% [2]. We report an unusual case of an adult patient with an aberrant adrenocortical tissue which is incidentally resected within lipoma of spermatic cord and identified on microscopic examination.

\section{Case Report}

A 52-year-old man presented with a swelling of the right inguinal region lasting for one week at the beginning of April, 2014. He had an average body mass index (BMI) of $23.99 \mathrm{~kg} / \mathrm{m}^{2}$. He had a history of atrial fibrillation and hypertension for 12 years and cerebral infarction 3 years ago. In addition, He experienced right retractile testis in the inguinal region while his asleep until high school student. However, he had never been diagnosed and treated with right undescended testis. He had no history of abdominal surgery. He was diagnosed with right inguinal hernia and admitted to Department of Gastroenterological Surgery, Muroran City General Hospital, Muroran, Japan, in late April 2014. His routine laboratory investigations were not remarkable except for serum triglyceride and total cholesterol level. He underwent transabdominal preperitoneal repair using Tilene mesh laparoscopically. However there was no significant hernia orifice intraoperatively. One month later he was still suffered from right inguinal swelling and underwent the 2nd operation via inguinal region (anterior open approach). When right external inguinal canal was opened, there was a fat-like tissue adhered to the spermatic cord. It was removed as much as possible and right spermatic cord and testis were preserved without any injury. There was no significant finding of right inguinal hernia again. Macroscopically aberrant adrenal tissue was not identified. Histopathological finding first revealed aberrant adrenocortical tissue in the resected lipoma of spermatic cord (Figure 1). There was no evidence of adrenomedullary tissue, hyperplasia and neoplasia.

After the 2nd operation, he was consulted to Department of Urology, Muroran City General Hospital. Although his right inguinal region was still swelling under the influence of operation, his bilateral testes were normally palpable in the scrotum. Postoperative adrenal hormone level in blood was normal. Preoperative Computed Tomography (CT) revealed that a fat-like mass run through the right pelvic cavity to inguinal region (Figure 2). In addition, bilateral adrenal glands were existed at normal position with normal size and there was no evidence of aberrant adrenal tissue on right inguinal region on preoperative CT. Postoperative Magnetic Resonance Image (MRI) revealed that there was no residual lipoma around right inguinal region (Figure 3). Although there was residual lipoma in the pelvic cavity (Figure 3), it is not clinically significant. Moreover, there was no evidence of residual ectopic adrenocortical tissue in the spermatic cord on postoperative MRI. Thus, he has received a usual follow-up without additional treatment.

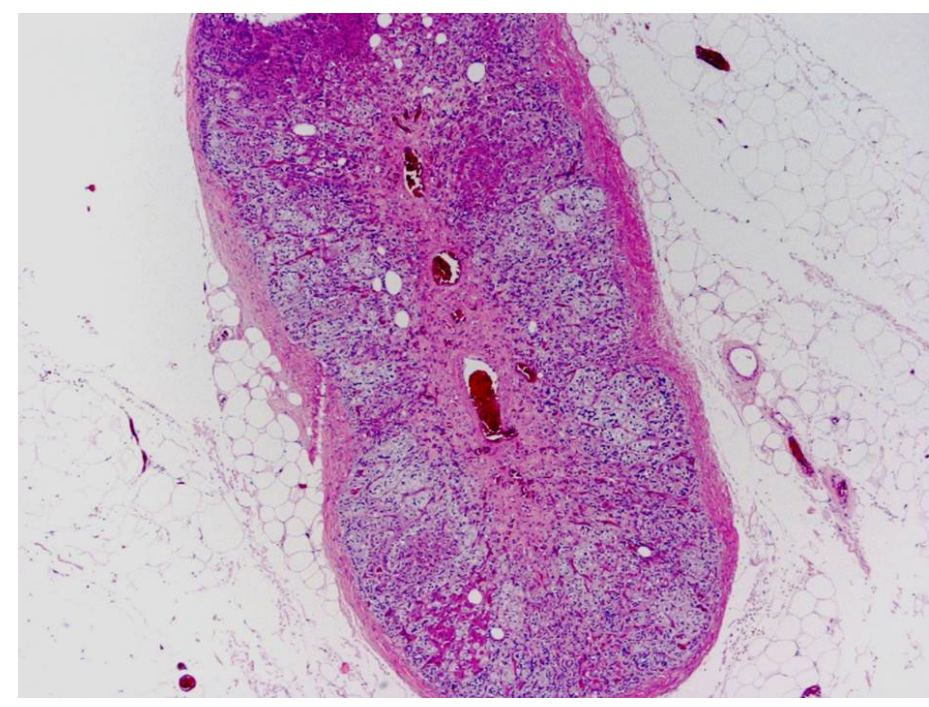

Figure 1. Adrenocortical tissue surrounded by an abundance of mature fat cells ( $\mathrm{H}$ and $\mathrm{E}$ stain $\times 40)$. 


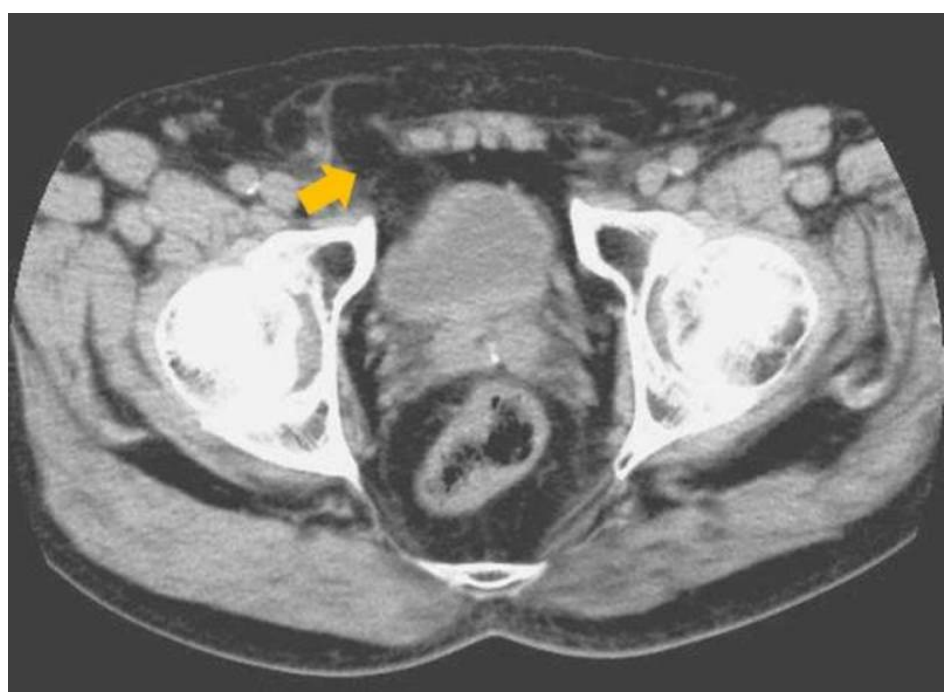

Figure 2. Preoperative Computed Tomography (CT) revealed that a fat-like mass run through the right pelvic cavity to the right inguinal region (arrow). There was no evidence of aberrant adrenal tissue.

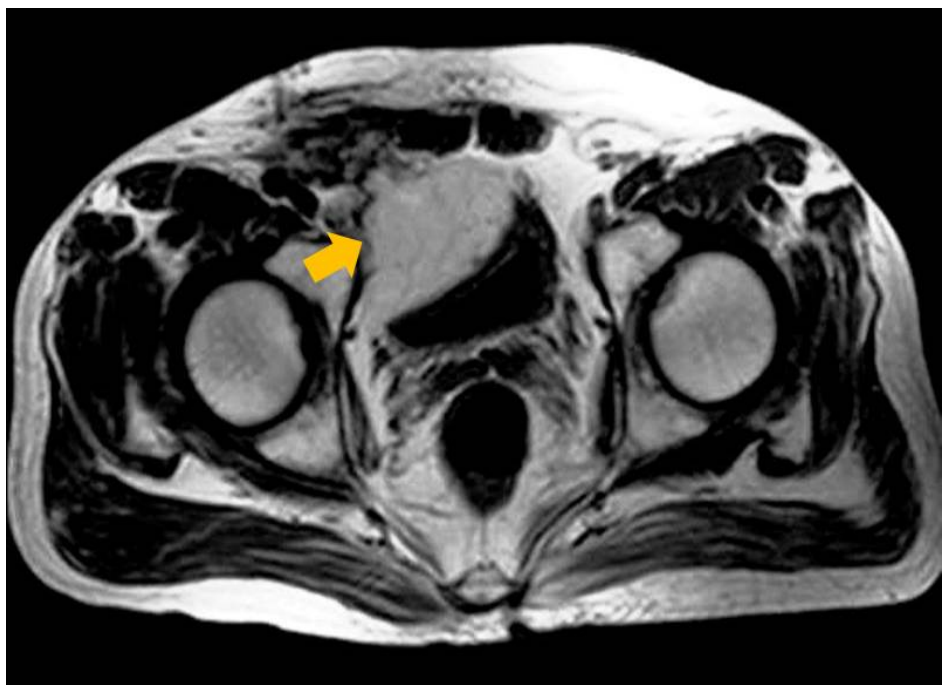

Figure 3. There was no residual lipoma around right inguinal region on postoperative Magnetic Resonance Image (MRI) although there was continuous unresected lipoma in the pelvic cavity (arrow).

\section{Discussion}

Aberrant adrenal tissue in structures around the spermatic cord and hernia sac is rare in adult. Most of the reported cases are in pediatric age group, with mean age of diagnosis of 5.6 years [3]. In addition, the majority of reported cases are in males. The lower incidence in girls is not easy to explain but may reflect differences in underlying diagnosis [4]. In adult population, the incidence of aberrant adrenal tissue in the spermatic cord is significant lower at 1\% [2]. Mendez et al. [3] reported 25 adult cases of aberrant adrenal tissue in the structures around the testes between 1949 and 2005. These abnormal tissue are usually found incidentally during inguinal operation and observed macroscopically as thin bright yellow nodules 1 - $5 \mathrm{~mm}$ in diameter and microscopically as lipid rich cortical cells without an adrenomedullary tissue [5]-[7].

The normal adrenal gland has a double embryological origin. Adrenal cortex that develops from the mesoderm media to the developing gonad and foci of the developing cortex may be carried with the descending gonad and lie in proximity with it. On the other hand, adrenal medulla develops from neuroectoderm by the 5th 
week and medulla is attached to the cortex by the 7th week of gestation [8]. As a result, the event for the generation of aberrant adrenocortical tissue is suspected to occur between 5th and 7th weeks of gestation. Thus, it is not surprising that aberrant adrenocortical tissue is usually found anywhere along the path of embryonic migration within the urogenital tract such as adnexa of the testes and spermatic cord.

Lilly et al. reported a retrospective review of 280 hernia repairs [9] and 63 lipomas of the spermatic cord were identified for an incidence of $22.5 \%$. They commented that a lipoma of the spermatic cord is herniated fat that appears to originate from the retroperitoneal fat outside and posterior to the internal spermatic fascia and protrudes thorough the internal ring lateral to the spermatic cord. They are generally not visible by transperitoneal inspection.

In this case, we suspected that aberrant adrenal tissue was occurred on a congenital basis within right spermatic cord and resected incidentally with lipoma which was posteriori occurred around right spermatic cord and led to the inguinal swelling. It was not clear whether a history of retractile right testes until early adolescence was associated with the origination of aberrant adrenal tissue and lipoma of the spermatic cord. In general, most of the aberrant adrenal tissue becomes atrophic by adult life [10]. Moreover, it is not clinically significant and also not associated with endocrine abnormalities. Nevertheless, the occurrence of pheochromocytoma and Cushing's syndrome associated with aberrant adrenal tissue has been reported [11] [12]. The patient in this case had a history of hypertension since early 40's. Although the preoperative adrenal hormone level remains unknown, postoperative hormone level is normal and the status of hypertension is not changed after the 2nd operation. Thus, we presumed this aberrant tissue was not biochemically and clinically significant preoperatively.

\section{Conclusion}

We reported a rare case of an adult patient with an aberrant adrenocortical tissue which is incidentally resected within lipoma of spermatic cord. Thus, in adult patient, aberrant adrenal tissue in the spermatic cord could be incidentally found during groin surgery and the majority of these cases are not clinically significant.

\section{References}

[1] Schechter, D.C. (1968) Aberrant Adrenal Tissue. Annals of Surgery, 167, 421-426. http://dx.doi.org/10.1097/00000658-196803000-00017

[2] Souverijns, G., Peene, P., Keuleers, H. and Vanbockrijck, M. (2000) Ectopic Localisation of Adrenal Cortex. European Radiology, 10, 1165-1168. http://dx.doi.org/10.1007/s003309900263

[3] Mendez, R., Tellado, M.G., Somoza, I., Liras, J., Sanchez-Abuin, A., Pais, E., et al. (2006) Ectopic Adrenal Tissue in the Spermatic Cord in Pediatric Patients: Surgical Implications. International Brazilian Journal of Urology, 32, 202207, Discussion 207. http://dx.doi.org/10.1590/S1677-55382006000200013

[4] Sullivan, J.G., Gohel, M. and Kinder, R.B. (2005) Ectopic Adrenocortical Tissue Found at Groin Exploration in Children: Incidence in Relation to Diagnosis, Age and Sex. BJU International, 95, 407-410. http://dx.doi.org/10.1111/j.1464-410X.2005.05310.x

[5] Savas, C., Candir, O., Bezir, M. and Cakmak, M. (2001) Ectopic Adrenocortical Nodules along the Spermatic Cord of Children. International Urology and Nephrology, 32, 681-685. http://dx.doi.org/10.1023/A:1014429119226

[6] Mares, A.J., Shkolnik, A., Sacks, M. and Feuchtwanger, M.M. (1980) Aberrant (Ectopic) Adrenocortical Tissue along the Spermatic Cord. Journal of Pediatric Surgery, 15, 289-292. http://dx.doi.org/10.1016/S0022-3468(80)80139-4

[7] Anderson, J.R. and Ross, A.H. (1980) Ectopic Adrenal Tissue in Adults. Postgraduate Medical Journal, 56, 806-808. http://dx.doi.org/10.1136/pgmj.56.661.806

[8] Ozel, S.K., Kazez, A. and Akpolat, N. (2007) Presence of Ectopic Adrenocortical Tissues in Inguinoscrotal Region Suggests an Association with Undescended Testis. Pediatric Surgery International, 23, 171-175. http://dx.doi.org/10.1007/s00383-006-1826-1

[9] Lilly, M.C. and Arregui, M.E. (2002) Lipomas of the Cord and Round Ligament. Annals of Surgery, 235, 586-590. http://dx.doi.org/10.1097/00000658-200204000-00018

[10] Czaplicki, M., Bablok, L., Kuzaka, B. and Janczewski, Z. (1985) Heterotopic Adrenal Tissue. International Urology and Nephrology, 17, 177-181. http://dx.doi.org/10.1007/BF02082491

[11] Abe, T., Matsuda, H., Shindo, J., Nonomura, K. and Koyanagi, T. (2000) Ectopic Pheochromocytoma Arising in the Spermatic Cord 5 Years after Removal of Bilateral Carotid Body Tumors and Adrenal Pheochromocytomas. International Journal of Urology, 7, 110-111. http://dx.doi.org/10.1046/j.1442-2042.2000.00143.x

[12] Ayala, A.R., Basaria, S., Udelsman, R., Westra, W.H. and Wand, G.S. (2000) Corticotropin-Independent Cushing’s Syndrome Caused by an Ectopic Adrenal Adenoma. The Journal of Clinical Endocrinology and Metabolism, 85, 2903-2906. 
Scientific Research Publishing (SCIRP) is one of the largest Open Access journal publishers. It is currently publishing more than 200 open access, online, peer-reviewed journals covering a wide range of academic disciplines. SCIRP serves the worldwide academic communities and contributes to the progress and application of science with its publication.

Other selected journals from SCIRP are listed as below. Submit your manuscript to us via either submit@scirp.org or Online Submission Portal.
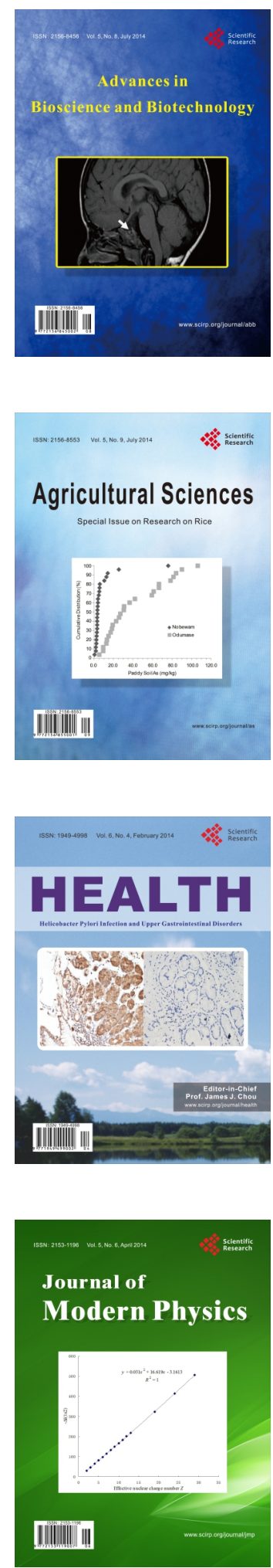
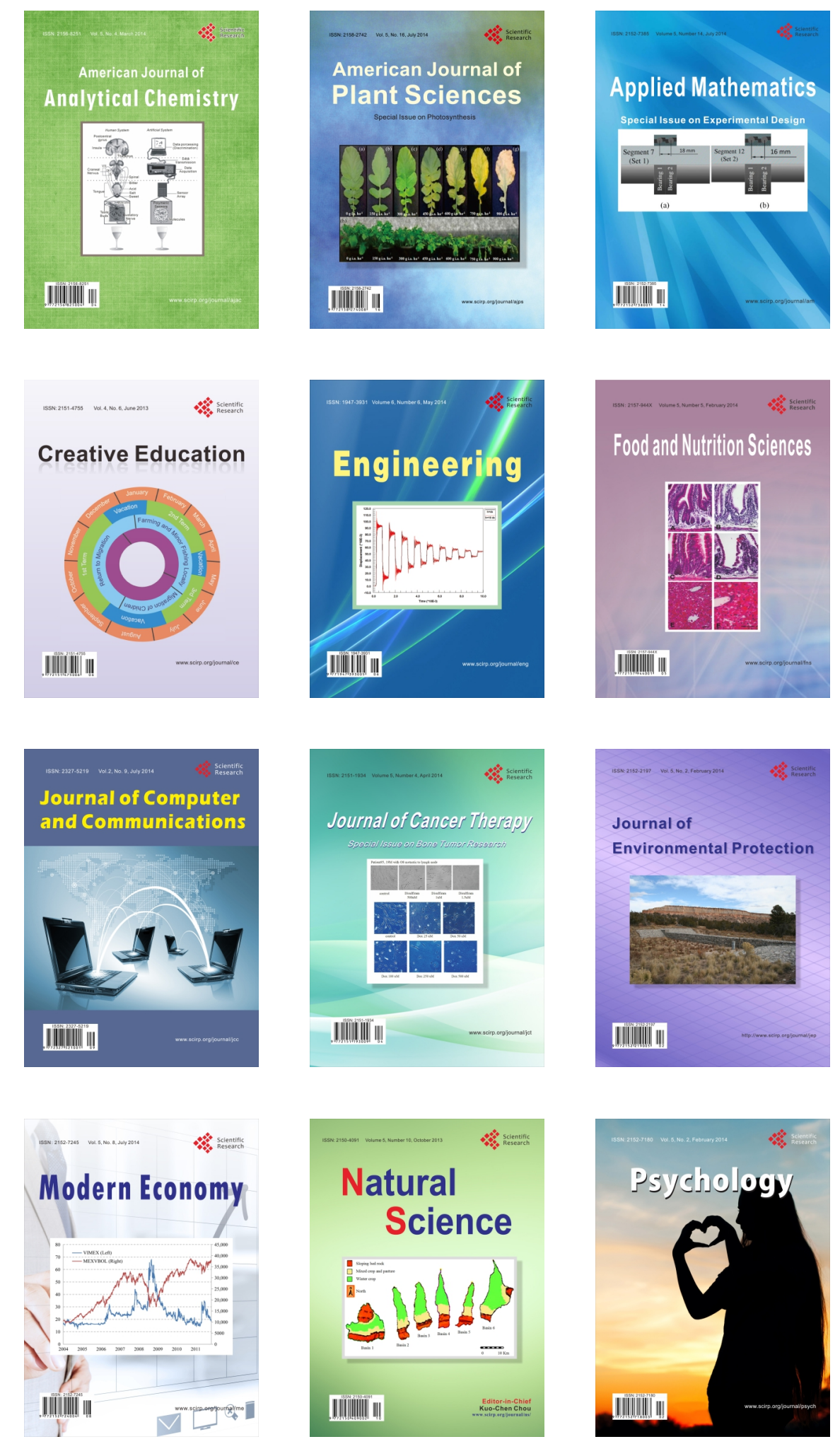